ARTIGO

\title{
O GOVERNO DA ADOLESCÊNCIA E SEUS DESLOCAMENTOS HISTÓRICOS
}

\author{
THIAGO BRANDÃO VIEIRA TAUHATA ${ }^{1}$ \\ ORCID: https://orcid.org/0000-0001-5979-1685 \\ TIAGO CASSOLI ${ }^{2}$ \\ ORCID: https://orcid.org/0000-0002-9751-124x
}

\begin{abstract}
RESUMO: O artigo problematiza, através da pesquisa genealógica, a emergência do adolescente em conflito com a lei. Buscar a emergência do adolescente em conflito com a lei significa buscar e descrever o conjunto de forças que, a partir de determinado acontecimento, permitiu o estabelecimento de uma nova configuração entre saberes e práticas sobre os corpos dos adolescentes. Argumentamos que o adolescente em conflito com a lei é uma personagem que emerge com o Estatuto da Criança e do Adolescente, sendo produzido pelas medidas socioeducativas, compreendidas como um conjunto de técnicas biopolíticas que articula tecnologias de dominação e tecnologias de si, no quadro de uma governamentalidade neoliberal. Desse modo, pretende contribuir com a crítica do presente mediante o recuo histórico de maneira a observar se o adolescente em conflito com a lei apresenta-se de fato como uma ruptura no campo dos saberes e das práticas institucionais e o sentido dessa ruptura.
\end{abstract}

Palavras-chave: Adolescente em conflito com a lei, biopolítica, governamentalidade, neoliberalismo.

\section{THE GOVERNMENT OF ADOLESCENCE AND ITS HISTORICAL DISPLACEMENTS}

\begin{abstract}
The article discusses, through genealogical research, the emergence of adolescents in conflict with the law. Seeking the emergence of adolescents in conflict with the law means to seek and describe the set of forces that, from a certain event, allowed the establishment of a new configuration between knowledge and practices on the bodies of adolescents. We argue that the adolescent in conflict with the law is a character that emerges with the Statute of Children and Adolescents, being produced by socio-educational measures, understood as a set of biopolitical techniques that articulate technologies of domination and technologies of themselves, within the framework of a neoliberal governmentality. In this way, it intends to contribute to the criticism of the present through the historical retreat in order to
\end{abstract}

\footnotetext{
${ }^{1}$ Universidade Federal de Goiás (UFG). Goiânia, GO, Brasil. < thiagotauhata@gmail.com.br >

${ }^{2}$ Universidade Federal de Goiás (UFG). Goiânia, GO, Brasil. < cassolitiago2@gmail.com.br > Educação em Revista|Belo Horizonte|v.36|e234615|2020
} 
observe if the adolescent in conflict with the law presents itself as a rupture in the field of knowledge, institutional practices and the meaning of this rupture.

Keywords: Adolescent in conflict with the law, biopolitics, governmentality, neoliberalism.

\section{EL GOBIERNO DE LA ADOLESCENCIA Y SUS DESPLAZAMIENTOS HISTÓRICOS}

RESÚMEN: El artículo problematiza, a través de la investigación genealógica, la emergencia del adolescente en conflicto con la ley. Buscar la emergencia del adolescente en conflicto con la ley significa buscar y describir el conjunto de fuerzas que, a partir de un determinado evento, permitieron el establecimiento de una nueva configuración entre el conocimiento y las prácticas en los cuerpos de los adolescentes. Argumentamos que el adolescente en conflicto con la ley es un personaje que emerge con el Estatuto del Niño y el Adolescente, que se produce mediante medidas socioeducativas, entendidas como un conjunto de técnicas biopolíticas que articulan tecnologías de dominación y tecnologías de sí mismas, en el marco de un gubernamentalidad neoliberal. De esta manera, pretende contribuir a la crítica del presente a través del retiro histórico para observar si el adolescente en conflicto con la ley se presenta como una ruptura en el campo del conocimiento, prácticas institucionales y el significado de esta ruptura.

Palabras clave: Adolescente en conflicto con la ley, biopolítica, gubernamentalidad, neoliberalismo.

\section{INTRODUÇÃO}

Neste artigo, observaremos a emergência do adolescente em conflito com a lei, a qual "se produz em um determinado estado das forças" (Foucault, 1979, p. 22). Portanto, analisamos algumas das forças envolvidas na emergência dessa personagem. Acreditamos que ela, conforme estabelecido pelo Estatuto da Criança e do Adolescente (ECA), emerge segundo sua objetivação por tecnologias biopolíticas no âmbito de uma governamentalidade neoliberal. Essas tecnologias, operando mediante um conjunto de conceitos e práticas denominadas medidas socioeducativas (MSE), objetivam-no de maneira distinta, representando uma ruptura com a figura do "menor".

Contudo, embora sua emergência represente uma ruptura com o "menor", criando um novo sujeito como resultado de uma ampla modificação institucional, discursiva e prática, permanece o adolescente em uma relação agônica com ele, seu antecessor direto. Conforme Sennellart (2006) sobre as artes de governar, não se trata só de ruptura nem de simples continuidade, mas de transições, deslocamentos de discursos e práticas anteriores que se infiltram em novos arranjos. As técnicas não substituem umas às outras. Como afirma Foucault (2008a):

\footnotetext{
Não há a era do legal, a era do disciplinar, a era da segurança. Vocês não têm mecanismos disciplinares, os quais teriam tomado o lugar dos mecanismos jurídico-legais. Na verdade, vocês têm uma série de edifícios complexos que vão se aperfeiçoar ou, em todo caso, se complicar, mas o que vai mudar, principalmente, é a dominante ou, mais exatamente, o sistema de correlação entre os mecanismos jurídico-legais, os mecanismos disciplinares e os mecanismos de segurança. (p.11)
} 
Consideração pertinente quando problematizamos a questão do adolescente em conflito com a lei a partir da governamentalidade, pois, conforme uma racionalidade neoliberal, os mecanismos legais, disciplinares e de segurança correlacionam-se de maneira a formar um dispositivo.

Segundo Foucault (1979), um dispositivo constitui-se como uma rede de elementos heterogêneos que "engloba discursos, instituições, organizações arquitetônicas, decisões regulamentares, leis, medidas administrativas, enunciados científicos, proposições filosóficas, morais e filantrópicas” (p. 244). Constituindo-se como a rede entre esses elementos, pode atuar como programa de uma instituição ou um modo de justificação, mascaramento ou reinterpretação de uma prática, fornecendo estrategicamente um novo campo de racionalidade em resposta a uma urgência (Foucault, 1979).

Daí, por um lado, a ruptura com a figura do "menor". O sistema de correlação entre os mecanismos institui um sujeito neste novo dispositivo em condição peculiar de desenvolvimento que é também um sujeito de direitos. Sob o paradigma da Proteção Integral do Estatuto, ele deve ser responsabilizado quando do cometimento de ato infracional mediante as MSE. Essas não devem punir o adolescente em conflito com a lei, mas responsabilizá-lo, instrumentalizando-o para desenvolver aptidões, habilidades e competências que permitam sua reinserção em uma sociedade neoliberal.

Por outro lado, porém, observamos o agonismo constante com o "menor" devido aos deslocamentos de mecanismos que se inscreveram sob novos arranjos, como a manutenção no ECA das medidas do Código de Menores de 1979 - a internação, desde o Código de Menores de 1927; de técnicas disciplinares de controle do espaço, do tempo e das atividades para a conformação de hábitos; de mecanismos de coerção e violência; de uma concepção menorista e higienista nas práticas institucionais.

Assim, problematizar a questão do adolescente em conflito com a lei consiste em descrever esse sistema de correlação entre mecanismos que, ao mesmo tempo que aponta uma "dominância", uma ruptura, com a produção de um novo sujeito, permanece em uma relação agônica com o "menor" pelo deslocamento de mecanismos anteriores. Portanto, iniciemos por essa relação agônica para melhor precisarmos a ruptura e os deslocamentos.

\section{AGONISMO: RUPTURA E DESLOCAMENTOS}

O adolescente em conflito com a lei emerge no plano jurídico com o ECA. Os Códigos de Menores, de 1927 e 1979, se não desconheciam a adolescência como uma fase específica, apreendiam-na apenas nominalmente. Fato é que no Código de Menores de 1979 não há uma menção sequer à adolescência ou ao adolescente, contrastando com o Código Mello Mattos, de 1927, no qual há ao menos uma menção ao adolescente e à adolescência (Art. 136 e Art. 222, Inciso X).

Contudo, essas menções nada mais fazem que citá-la, reconhecendo a sua existência, colocando-a como algo distinto da criança e da infância, sem precisá-la. Apesar desse reconhecimento, não há qualquer disposição no Código Mello Mattos que implique práticas distintas para lidar com a criança e o adolescente. De fato, não há conceituação alguma de criança. Apesar da utilização dos termos, é sob a égide do "menor" que ambos são articulados no discurso jurídico.

A própria definição de "menor" no Código de 1927 apresenta-nos claramente a quem se destina. Neste, "menor" não diz respeito a todos com menos de 18 anos, mas aos "menores" abandonados e delinquentes que serão submetidos pela autoridade competente às medidas de assistência e proteção definidas pelo mesmo (1927, Art. $\left.1^{\circ}\right)$. A criança e o adolescente constituem-se como 
problemas do Estado quando em estado de abandono e deliquência, quando objetivados como "menores".

No Código de 1979, os "menores” são explicitamente definidos conforme sua situação. O artigo $1^{\circ}$ dispõe acerca da assistência, proteção e vigilância de menores até 18 anos que se encontrem em situação irregular. Essas podem se dar em função de o menor "encontrar-se privado de condições essenciais à subsistência, saúde e instrução"; "vítima de maus-tratos e castigos imoderados"; "em perigo moral"; "privado de representação ou assistência legal"; "apresentar desvio de conduta, em virtude de grave inadaptação familiar ou comunitária"; “autor de ato infracional” (Lei n. ${ }^{\circ}$ 6.697, 1979, Art. $2^{\circ}$, Inciso I-V).

A substância do "menor" não se encontra diretamente na lei, mas nos saberes responsáveis por seu exame, apontando ou não sua perversão, o perigo de ser pervertido, sua periculosidade. Não há substância, somente distintas objetivações adequando-se indefinidamente às múltiplas demandas.

No ECA, contudo, a lei já integra a concepção normativa quando concebe a criança e o adolescente como etapas peculiares do desenvolvimento. Lei e norma integram-se no ECA. Ainda que possamos falar em norma jurídica, não há identificação entre a lei e a norma. Ao passo que a lei se destina às condutas individuais, declarando-as permitidas ou proibidas, mediante um corpus de códigos e textos, a norma tem um campo de exercício muito mais amplo. Ela estabelece para os atos todo um domínio no qual se efetuará a comparação, a distinção e o estabelecimento da regra (Foucault, 1987). Ela busca homogeneizar, permite a valoração das condutas, hierarquiza-as e, em seu limite, determina o normal e o anormal.

Ao descrever as legislações específicas destinadas ao governo da adolescência, tomamos o ECA como um desenvolvimento, no sentido de que é representativo de uma lei que "funciona cada vez mais como uma norma" e de uma "instituição judicial" que "se integra mais e mais a um continuum de aparatos (médicos, administrativos, etc.) cujas funções são sobretudo reguladoras” (Foucault, 2018, p.156).

É este um dos pontos cruciais do próprio Estatuto como vimos no debate promovido pela Pontifícia Universidade Católica do Rio de Janeiro, em 1989, no evento "A Criança e seus Direitos: Estatuto da Criança e do Adolescente e Código de Menores em Debate".

Nesse debate, Deodato Rivera (1989) afirma a enorme distinção entre o ECA e o Código de Menores apontando algumas concepções:

No paradigma da PROTEÇÃO INTEGRAL, a primeira concepção ordenadora diz assim: criança e adolescente são SUJEITOS DE DIREITOS. Isso é importantíssimo, tem consequências muito sérias para a nova legislação. No paradigma II crianças e adolescentes não são sujeitos de direitos. Isso vem sendo dito, inclusive pelos autores da Lei do Código de Menores: criança não tem direitos, só tem necessidades. Está dito até em livros. Bom, nesse paradigma só há um direito que é à assistência religiosa quando o menino está preso. Então, não há direitos, são objetos de medidas. São objetos de medidas judiciais.

A outra concepção ordenadora fundamental é a definição do destinatário da norma. Esta é a sua CONDIÇÃO PECULIAR DE PESSOA EM DESENVOLVIMENTO no paradigma I. Isto é um termo constitucional que não foi posto ali à toa: "condição peculiar de pessoa em desenvolvimento". Isso tem um embasamento científico. É a definição ontológica do ser bio-psico-sócio-cultural criança e adolescente. No outro paradigma, onde está essa condição peculiar? Ela está simplesmente na designação de "menor", um adjetivo que, por uso e abuso na prática social discriminatória, e na Doutrina da Situação Irregular - da patologia social - foi transformado em substantivo. Mas ele escamoteia a essência, a ontologia, a referência deste conceito. Qual é o referente deste conceito? É a criança ou é um adolescente. (p. 49 e 50, grifos do autor). 
O trecho permite-nos constatar a disposição de força dos saberes que adentraram a esfera jurídica. O referente, a substância, encontra-se na ordenação legal através da condição peculiar de pessoa em desenvolvimento, possibilitando a definição jurídico-ontológica da criança e do adolescente, seres bio-psico-sócio-culturais, sujeitos de direitos.

Norma e lei convergem e se confundem. Integram-se a tal ponto que podemos ver como a junção entre ambas, na própria legislação, acaba por implicar também o atravessamento permanente na instituição judiciária de outros saberes:

Este é um livro sobre a infância, a lei e a democracia. Porém, sobretudo é um livro sobre a lei. No entanto, a grande maioria dos autores constitui apenas uma (pequena) parte dos novos e heterodoxos "advogados" produtos do movimento de luta pelos direitos da infância na América Latina: advogados-psicólogos, advogados-pedagogos, advogados-arquitetos, assistentes sociais, economistas, sociólogos e até advogadosadvogados. (Méndez, 2001, p. 15)

O direito da criança e do adolescente apresenta-se como um espaço de atravessamentos diversos, tanto em sua constituição quanto em seu cotidiano de funcionamento, desde o momento em que a lei integrou especificamente a concepção desenvolvimentista que permitiu a distinção entre a criança e o adolescente e conduziu este último à responsabilização penal. Como afirma Méndez:

El modelo de responsabilidad penal de los adolescentes constituye una ruptura profunda, tanto con el modelo tutelar, cuanto con el modelo penal indiferenciado, que hoy se expresa exclusivamente en la ignorante o cínica propuesta de baja de la edad de la imputabilidad penal.

Por su parte, el modelo del ECA demuestra que es posible y necesario superar tanto la visión pseudo-progresista y falsamente compasiva de un paternalismo ingenuo de carácter tutelar, cuanto la visión retrógrada de un retribucionismo hipócrita de mero carácter penal represivo. El modelo de la responsabilidad penal de los adolescentes (de ahora en adelante RPA) es el modelo de la justicia y de las garantías.

El modelo de la RPA dispuesto por el ECA posee algunas características esenciales que vale la pena poner aquí en evidencia. En primer lugar y a pesar que la CIDN, sobre todo en su caráter de instrumento jurídico de carácter universal, define como niño a todo ser humano hasta los dieciocho años incompletos, el ECA parte por diferenciar jurídicamente situaciones que el sentido común y la psicología evolutiva ya distinguían hace mucho tiempo: que no es lo mismo un ser humano de cuatro años que uno de diecisiete. (Méndez, 2006, p. 11)

Nessa distinção, observamos o ponto de tensionamento a ressaltar. A teoria do desenvolvimento, mediante a perspectiva evolutiva que caracterizou a adolescência como uma fase ambígua, situou nela uma periculosidade natural, imanente à própria fase (César, 2008). Mesmo sendo atravessada por diversos outros saberes que por vezes retiram do âmbito da natureza sua periculosidade, o sinal do perigo não foi retirado (César, 2008). Natural, psicológica, social ou culturalmente, a adolescência é uma fase arriscada, sendo, pois, um dispositivo que emerge entre a infância e a maturidade como fase indefinida, constituindo um sujeito nem completamente responsável, mas tampouco inocente.

Assim, crianças e adolescentes são distintos, mas ao adolescente a responsabilização penal, em nosso caso, socioeducativa, é reservada. A concepção desenvolvimentista que se apresenta no próprio Estatuto, mais que permitir a distinção entre criança e adolescente, constitui este como um sujeito a ser responsabilizado.

Haveria, porém, alguma normativa jurídica que distinguisse a infância da adolescência ou observamos o atravessamento dos discursos das ciências para o discurso jurídico? Os organismos internacionais certamente pressionaram para as transformações no Direito de Menores, mas estabeleceram eles esta distinção entre criança e adolescente?

No primeiro documento internacional direcionado à proteção das crianças, a Declaração de Genebra, de 1924, não há conceito ou definição da infância ou da criança. A Declaração Universal dos Direitos Humanos (Assembleia Geral das Nações Unidas, Resolução 217 A (III), de 10 de dezembro de 1948), citará a infância e a criança no $2^{\circ}$ parágrafo do artigo XXV sem defini-las. Igualmente se 
apresentam na Declaração Universal dos Direitos da Criança, adotada pela Assembleia das Nações Unidas em 20 de novembro de 1959 (Resolução 1386 (XIV)). Ausente nesses documentos está qualquer menção à adolescência.

Nas Regras Mínimas das Nações Unidas para a Administração da Justiça da Infância e da Juventude, conhecidas também como Regras de Beijing (1985), não se encontram definições acerca da infância e da adolescência, da criança e do adolescente, mas, diferentemente das Declarações anteriores, buscam definir o jovem. Segundo o item 2.2 dos princípios gerais para a administração da justiça, "jovem é toda a criança ou adolescente que, de acordo com o sistema jurídico respectivo, pode responder por uma infração de forma diferente do adulto.” (Assembleia Geral das Nações Unidas, Resolução 40/33, de 29 de novembro de 1985).

Dista, portanto, de uma concepção da criança e do(a) adolescente como dados naturais. Considera-os conforme o próprio campo legal, definindo-os a partir dos respectivos sistemas jurídicos e a resposta diferenciada dada pelos mesmos à infração cometida por aqueles. Neste ponto, insere-se nas normativas internacionais o jovem, em 1985, englobando tanto a criança como o adolescente ainda indefinidos nas normas internacionais.

Somente na Convenção da Organização das Nações Unidas dos Direitos da Criança, de 1989, ratificada pelo Brasil no Decreto n. ${ }^{\circ} 99.710$ (1990), à criança foi atribuída a seguinte definição em seu artigo $1^{\circ}$ da Parte I: "Para efeito da presente convenção considera-se criança todo ser humano com menos de 18 anos de idade, a não ser que, em conformidade com a lei aplicável à criança, a maioridade seja alcançada antes". Não há distinção entre a criança e o adolescente em faixas etárias distintas ou segundo uma concepção desenvolvimentista; abaixo dos 18 anos, a Convenção considera todos como crianças.

Nas Diretrizes das Nações Unidas para Prevenção da Delinquência Juvenil, ou Diretrizes de Riad, de 1990, encontramos muitas referências ao jovem, sem definição explícita. Nas Regras das Nações Unidas para a Proteção dos Jovens Privados de Liberdade, de mesma data, o termo “jovem” refere-se a qualquer pessoa com menos de 18 anos.

Criança, para a Convenção, é todo ser humano com menos de 18 anos de idade; jovem, segundo as Regras das Nações Unidas para a Proteção dos Jovens Privados de Liberdade, qualquer pessoa com menos de 18 anos ou, ainda, segundo as Regras de Beijing, toda criança ou adolescente que, ao cometer uma infração, responde por ela de forma diferente do adulto.

Observamos que não há, nos documentos internacionais, uma definição ontológica a atravessar o discurso jurídico. De fato, a distinção é efetuada segundo objetivos específicos: quando da proteção, crianças; quando da responsabilização, jovens. O critério, porém, se estabelece conforme o conjunto das leis de cada país.

A constituição da adolescência como uma categoria jurídica não encontra paralelo nos documentos internacionais. O ECA apresenta-se como um evidente exemplo da biopolítica ao estabelecer, na própria legislação, uma concepção sobre o homem, homem-espécie, segundo etapas específicas de desenvolvimento, e determinando para esse homem, pessoa em desenvolvimento, mecanismos específicos de regulação.

Essa maneira de objetivar o sujeito apresenta perfeitamente uma expressão do poder que pouco tem a ver com um exercício conforme os desejos de um soberano ou as determinações de um Estado autoritário. Antes procura regular e administrar os processos da própria vida no nível da população, incidindo sobre os seres vivos que são concomitantemente sujeitos biológicos e jurídicos. 
Assim, "o biológico reflete-se no político", "a vida e seus mecanismos" entram "no domínio dos cálculos explícitos" e a "espécie entra como algo em jogo em suas próprias estratégias políticas" (Foucault, 2018, p. 154).

A adolescência que emerge como um dispositivo, no qual participam de maneira concertada diversas práticas e discursividades, tem com o ECA uma reconfiguração que atende a uma função estratégica de regulação e governo da infância e da adolescência após o esgotamento do dispositivo "menor".

Os critérios circunstanciais, da situação irregular, são substituídos pela universalidade do ECA que não só abrange toda a infância e adolescência, tornando-as objeto de práticas e discursividades distintas, como permite o estabelecimento de toda uma série de variações e também de tecnologias de governo adequadas a sua regulação. Cria-se um campo consideravelmente maior no qual se pode estabelecer relações estratégicas mais diversas, sendo, pois, um refinamento no exercício do poder.

O modo de relação próprio ao poder não deveria, portanto, ser buscado do lado da violência e da luta, nem do lado do contrato e da aliança voluntária (que não podem ser mais do que instrumentos); porém, do lado deste modo de ação singular - nem guerreiro nem jurídico - que é o governo. (Foucault, 1995, p. 244)

O modo de relação próprio ao poder deve ser então buscado no modo de ação singular que é o governo, uma "conduta sobre condutas".

O termo "conduta", apesar de sua natureza equívoca, talvez seja um daqueles que melhor permite atingir aquilo que há de específico nas relações de poder. A "conduta" é, ao mesmo tempo, o ato de "conduzir" os outros (segundo mecanismos de coerção mais ou menos estritos) e a maneira de se comportar num campo mais ou menos aberto de possibilidades. O exercício do poder consiste em "conduzir condutas" e em ordenar a probabilidade. O poder, no fundo, é menos da ordem do afrontamento entre dois adversários, ou do vínculo de um com relação ao outro, do que da ordem do "governo". (Foucault, 1995, p. 288)

Governo e poder não se restringem e tampouco se fundamentam ou se identificam plenamente com a violência ou com o contrato, mas se servem deles como instrumentos. Ambos ordenam probabilidades, visto que não se objetivam apenas ao corpo vítima da violência, mas ao corpo da população. Contudo, não são suficientes para gerir tanto a população quanto os indivíduos.

É nesse contexto que mesmo um Estado autoritário, que frequentemente recorre à violência para gerir a população, necessita desenvolver outras técnicas para "conduzir as condutas" e para tanto necessita conhecer aqueles que busca governar.

Presenciamos, ao longo do século XX, no que concerne à criança e ao adolescente, o exercício de técnicas biopolíticas que, embora flertem com o liberalismo, coordenaram-se mais especificamente segundo uma racionalidade característica dos Estados totalitários, com o Estado encontrando em si próprio o objetivo e a legitimidade para o exercício do governo.

O golpe de Estado apresenta-se não como um confisco do Estado por uns em detrimento de outros, mas a afirmação de uma razão que coloca a necessidade de salvar o Estado, quaisquer que sejam os meios, sobre todas as demais: "O golpe de Estado é a automanifestação do próprio Estado" (Foucault, 2008a, p. 350). Ele se apresenta como meio e objetivo, simultaneamente.

Desde 1930, as instituições que recebiam menores eram divididas em institutos oficiais, mantidos pelo governo por verbas do Ministério da Educação e Saúde e administrados por associações civis; e os particulares, contratados pelo Ministério da Justiça, para a internação de menores, mediante pagamento de quota mensal por menor. 
Em 1932, Vargas emitira um apelo aos governadores dos Estados em prol da infância:

(...) nenhuma obra patriótica, intimamente ligada ao aperfeiçoamento da raça e ao progresso do país, excede a esta, devendo constituir, por isso, preocupação verdadeiramente nacional. Os poderes públicos, aliados à iniciativa particular e guiados pelo estudo atento e científico dos fatos, têm no amparo à criança, sobretudo, quanto à preservação da vida, conservação da saúde e ao seu desenvolvimento físico e mental, um problema da maior transcendência, chave da nossa opulência futura, principalmente na nossa terra, onde, mais talvez que nas outras, se acumulam fatores nocivos à formação de uma raça forte e sadia. O índice de mortalidade infantil é, na própria capital da República, só comparável ao das grandes cidades tropicais da África e da Ásia e no resto do país, as cifras são desoladoras. A hora impõe-nos zelar pela nacionalidade, cuidando das crianças de hoje, para transformá-las em cidadãos fortes e capazes. (In Rizzini, 2011, p. 247)

O "menor" constituía-se como um objeto a ser manipulado para a obtenção desse fim cuja valorização se dava mediante uma identificação com o Estado. Após o golpe, em 1940, institui-se o Serviço de Atendimento ao Menor (SAM), que centraliza as ações e permite ao Estado executar todo o trabalho direcionado aos "menores delinquentes e abandonados".

O Estado Novo estabelecia uma política nítida de distinção entre os menores e a criança mediante a criação de órgãos federais especializados, o SAM e o Departamento Nacional da Criança (DNCr) (Rizzini, 2011). Sendo o SAM um órgão do Ministério da Justiça, ele funcionava como um equivalente do sistema penitenciário para os menores de idade, focalizando a ação correcional e repressiva (Saraiva, 2016).

Os menores delinquentes começavam a ser encarados sob uma nova perspectiva no Estado Novo. Então, com o Decreto-Lei n. ${ }^{\circ}$ 6.026, de 1943, o menor passa a ser explicitamente denominado como perigoso (Art. $2^{\circ}, \sqrt{ } 1^{\circ}$ ), podendo ser internado em uma secção especial destinada a adultos até que sua periculosidade fosse considerada cessada. Observava-se que o disposto no Decreto-Lei n. ${ }^{\circ}$ 3.914, de 1941, em seu artigo $7^{\circ}$, parágrafos $2^{\circ}$ e $3^{\circ}$, determinava o envio após os 21 anos para a colônia agrícola ou instituto de trabalho, de reeducação ou de ensino profissional.

As instituições sofrem suas alterações no quadro do Estado Novo: "a 'governamentalização' pretendeu atingir toda a sociedade e para isso institui o paternalismo assistencial” (Passetti, 2016, p. 362). O SAM possuía justamente a finalidade de "sistematizar e orientar os serviços de assistência a menores desvalidos e delinquentes, internados em estabelecimentos oficiais e particulares" (Lei n. ${ }^{\circ}$ 3.199, 1941, art. $2^{\circ}$, alínea a).

O artigo segundo dá o teor do aprofundamento dos saberes em parceria com os objetivos do Estado. Nele observamos, além da "investigação social", a realização do "exame médicopsicopedagógico" dos menores para, recolhidos a "estabelecimentos adequados", "ministrar-lhes educação, instrução e tratamento sômato-psíquico, até seu desligamento" (Idem, alíneas b-c).

Em 1964, a Fundação Nacional do Bem-Estar do Menor (FUNABEM) intensifica significativamente o controle do Estado das instituições destinadas ao "menor infrator". A Funabem apresentava, entre suas diretrizes, "assegurar prioridade aos programas que visem à integração do menor na comunidade, através de assistência na própria família e da colocação em lares substitutos” (Art. $6^{\circ}$, inciso I). Contudo, é a prática repressiva e correcional que é aprimorada com uma centralização efetiva da esfera federal sobre os governos estaduais.

A Funabem orientava-se, pragmaticamente, para manter a ordem social, alegando os riscos à mesma advindos do movimento comunista. A intervenção sobre a população adolescente mostrava-se 
como uma necessidade para a manutenção da segurança nacional. Para efetuar essa tarefa, contava com autonomia financeira significativa para a época (Rizzini \& Celestino, 2016).

Rapidamente, segundo Faleiros (2011), no contexto repressivo do Regime Militar, a Funabem torna-se um instrumento tecnocrático e autoritário para o controle social em nome da segurança nacional. A centralização instituída anteriormente encontra seu aprimoramento com a Política Nacional do Bem-Estar do Menor (PNBM), mais vertical e centralizadora do que fora o SAM (Faleiros, 2011).

Os menores, encarados como uma "patologia social" (Saraiva, 2016, p. 54), tomavam a marginalização a partir de um ângulo não tão diferente do que se expressara anteriormente. Causada por problemas como o esfacelamento da família, a migração e a urbanização, nada de novo surgia na forma de compreender o problema. Contudo, se nada de novo surgia na compreensão, a proposta de resolução encontrava na Unidade do Sistema sua garantia de eficácia.

O Sistema era a forma como se denominava tanto a política da infância quanto o conjunto de mecanismos de repressão, de controle social e político, em sua ânsia por estar presente em todas as partes, controlando, vigiando, educando e processando de acordo com o plano racional tecnocrático (Faleiros, 2011).

Um novo quadro de profissionais de diversas áreas do conhecimento é convocado para os quadros da Funabem para lidar com os menores. Durante a vigência do PNBM, uma metodologia interdisciplinar redimensiona a ideia de periculosidade que até então se mostrava restrita à área médica (Passetti, 2016). A nova metodologia científica tinha a alegada função de transformar as repressivas práticas anteriores mediante a aplicação de uma grade mais ampla, de tudo aquilo que poderia se situar sob o conceito de biopsicossocial.

A política de "menores" do governo militar é o melhor exemplo de uma biopolítica no quadro de um governo autoritário no cenário brasileiro. Atuando conforme os objetivos de ordenação e defesa social, tornou os "menores" objeto por excelência de uma prática despótica.

O novo Código de Menores (Lei 6.697, 1979) instituiu o paradigma da Situação Irregular incluindo "praticamente 70\% da população infanto-juvenil brasileira" (Saraiva, 2016, p. 54). Sob a égide da situação irregular, uma vez mais se conduziam menores tanto por sua conduta quanto por questões completamente alheias a eles.

Vemos, assim, a produção do "menor" como objeto da lei. Sem quaisquer garantias legais, todo um aparato administrativo-judiciário destinava-se a produzir com esses objetos os cidadãos adequados a se submeterem a uma política autoritária e centralizadora, conformando-os aos espaços e atividades específicos a eles destinados.

O ECA, porém, é elaborado segundo uma nova racionalidade. A governamentalidade que começa por se instituir com a redemocratização é elaborada em contraponto ao governo ditatorial. A nova governamentalidade não compreende um Estado que toma a si próprio como referente, guiado e legitimado por seus próprios interesses de crescimento, fazendo o uso arbitrário dos meios disponíveis, especialmente da coerção e da violência.

A nova razão de Estado deve atender a algum interesse externo a si próprio. Melhor, interesses. Para além da unicidade do Estado como fonte e objetivo do governo, há uma série de elementos, cada um dos quais com seus próprios interesses, constituindo forças que deverão não só ser reconhecidas, mas articuladas entre si. Segundo Foucault (2008b): 
Agora, o interesse a cujo princípio a razão governamental deve obedecer são interesses, é um jogo complexo entre os interesses individuais e coletivos, a utilidade social e o benefício econômico, entre o equilíbrio do mercado e o regime do poder público, é um jogo complexo entre direitos fundamentais e independência dos governados. O governo, em todo caso o governo nessa nova razão governamental, é algo que manipula interesses. (p. 61)

Mediante essa manipulação de interesses, o governo da adolescência em conflito com a lei se estabelece. Ao mesmo tempo que preconiza a proteção integral e estabelece instituições para operacionalizá-las, também estabelece, a partir de outras instituições, práticas que se chocam diretamente com sua proteção integral. O dispositivo "menor" não atende à pluralidade de interesses, mas o ECA permite, além de uma reconfiguração do dispositivo "menor" com o adolescente em conflito com a lei, novos arranjos desses interesses nas práticas de governo de toda a infância e adolescência.

Sob o paradigma da Proteção Integral, princípio pelo qual todas as disposições do Estatuto devem ser interpretadas em benefício da criança e do adolescente, visando a sua proteção, e as MSE, que representam uma sanção do Estado, as práticas de proteção e punição veem-se unificadas nas mesmas medidas, instituindo o agonismo de nossa personagem.

\section{GOVERNAMENTALIDADE: MENORES E ADOLESCENTES}

Pretendemos, porém, explicitar que a governamentalidade que se apresenta no ECA é em muito distinta da dos Códigos de Menores. Ela procura impedir a centralização de ações, decisões, fiscalização. Como a Constituição de 1988, o ECA estabelece as diretrizes de um aparato jurídicocientífico-administrativo que procura limitar o Estado, visando impedir uma conduta autoritária e arbitrária sobre as condutas com o foco no próprio Estado.

As diretrizes de atendimento (ECA, artigo 88) preconizam sua descentralização segundo instâncias distintas. Essas diretrizes, ao mesmo tempo que impedem a centralização, que se dava desde o Código Mello Mattos, constituem um campo para um novo jogo. Nesse campo, responsabilidades são partilhadas, mas também negadas, empurradas entre as diversas políticas públicas que acabam por não se integrar, fragmentando o objeto conforme múltiplas objetivações ainda que regidas por um mesmo Estatuto.

Isso resulta não só em um adolescente múltiplo, mas em um sujeito de direitos particularmente problemático: o "adolescente em conflito com a lei”, fragmentado entre as diversas instituições, objetivado segundo programas e ações distintas em cada uma das políticas. A circunstância de "conflito com a lei" acaba por se tornar um termo desorganizador capaz de interromper ou gerar novas distinções em cada um dos programas. O que mantém tensionado o adolescente não entre a criança e o adulto somente, mas conforme o termo desorganizador entre o "menor delinquente" e o "criminoso adulto." Daí a permanente discussão entre o prolongamento do tempo de internação e a redução da maioridade penal.

Sua objetivação, segundo uma governamentalidade liberal, não exclui uma série de práticas e discursos menoristas e higienistas, pois ela permanece atuando seja no âmbito do discurso político quanto na prática judiciária e institucional (Feitosa \& Boarini, 2014; Giangarelli \& Rocha, 2011) -, mas tampouco se reduz a ela. A governamentalidade liberal também estabeleceu novas formas de regulação ao mesmo 
tempo que instituiu uma nova chave interpretativa, preenchendo estrategicamente o dispositivo. Não causa surpresa que se possa afirmar que:

Na área que regula conflitos de natureza penal - que é o lugar onde seguramente se jogará, a curto prazo, a
sorte de todas estas reformas legislativas - o objetivo consistiu na consideração do adolescente infrator como
uma precisa categoria jurídica, abandonando o discurso pseudoprotecionista que, considerando-o uma vaga
categoria social, infringia os mesmos "tratamentos" discricionários independentemente de sua situação jurídica
concreta, na realidade meros eufemismos para encobrir um sistema punitivo sem limites nem garantias. (Méndez, 2001, p. 19)

O governo do adolescente em conflito com a lei requer outro tipo de sistema para regular os conflitos de natureza penal. Aquilo que se preconizara no início do século XIX no Brasil para o sistema penal, de humanização das penas, tem na área da conduta infracional do adolescente sua atualização.

$\mathrm{O}$ adolescente, sujeito biológico e jurídico, sequer responde penalmente às suas infrações. Quando do cometimento do ato infracional, determina-se uma sanção pedagógica, uma das medidas socieducativas, conforme a capacidade do adolescente em cumpri-la e dela se beneficiar (Digiácomo \& Digiácomo, 2017; Saraiva, 2016).

A humanização que se apresenta, para Rivera (A Criança e seus Direitos: Estatuto da Criança e do Adolescente e Código de Menores em Debate, 1989), como um princípio fundamental é não só um dos pontos-chave do Estatuto, mas um dos elementos estratégicos de uma nova governamentalidade.

Para Cassoli (2016), a humanização em Foucault emerge justamente na crítica a uma lógica punitiva ineficaz. A humanização, como estratégia da biopolítica neoliberal, cria tecnonologias mais sutis de governo e controle do sujeito. Evita-se a produção da dor como tática de governo e investe-se na produção de subjetividades, de desejos, de produção de capital humano a partir de um controle que se exerce pelo empreendedorismo. Não se deve castigar, mas corrigir por meio de um "caráter educativo e ortopédico por meio da vigilância, da extração da verdade e da "liberdade": "o que está em questão é a alma do sujeito (...) a consciência dele em relação à falta e ao erro cometido: as más condutas." (Cassoli, 2016, p.114).

Sabemos que a "humanização" está na origem das próprias políticas destinadas à infância e adolescência, mas a governamentalidade na qual se procurou exercer essa prática humanizada de assistência e punição estabeleceu limites intransponíveis devido às frágeis alianças entre o Estado e os saberes das respectivas épocas. Todavia, no Estatuto, as condições históricas tornam possíveis pensar a humanização segundo uma nova governamentalidade.

A racionalidade liberal presente no ECA parece-nos evidente. O Estatuto estabelece as diretrizes de governo da criança e do adolescente articulando interesses individuais e coletivos e limitando a ação do Estado. Tomando como critério os próprios sujeitos, seres humanos e sujeitos de direitos, ele produz uma determinada liberdade regulada conforme certa racionalidade.

É assim que as técnicas biopolíticas são, com o Estatuto, colocadas em seu quadro de origem. Biopolítica e governamentalidade relacionam-se diretamente: uma surge no contexto da outra. Foucault (2008b) compreende o "liberalismo como quadro geral da biopolítica" (p. 30). A questão da biopolítica não pode se dissociar

(...) do âmbito de racionalidade política no interior do qual eles apareceram e adquiriam sua acuidade. A saber, o "liberalismo", já que foi em relação a ele que adquiriram o aspecto de um verdadeiro desafio. Num sistema preocupado com o respeito dos sujeitos de direito e com a liberdade dos indivíduos, como é que o fenômeno 
"população" com seus efeitos e seus problemas específicos pode ser levado em conta? Em nome do que e segundo que regras pode ser ele administrado? (Foucault, 2008b, pp. 431-432)

Afirmamos, porém, em diversos momentos, que o governo do adolescente em conflito com a lei se dá conforme uma governamentalidade neoliberal. A concepção liberal do ECA não é um simples prenúncio, uma etapa anterior, assim como o neoliberalismo não é a simples continuidade ou desenvolvimento do liberalismo. Enquanto este opera na limitação do Estado, estabelecendo no mercado um espaço de veridicção da prática governamental, aquele aplicará sobre todas as atividades humanas a grade de inteligibilidade dos processos econômicos (Foucault, 2008b). Conforme afirma Foucault (2008b), o homo penalis e o bomo oeconomicus são correlatos:

O homo penalis, o homem que é penalizável, o homem que se expõe à lei e pode ser punido pela lei, esse homo penalis é, no sentido estrito, um homo oeconomicus. E é a lei que permite, precisamente, articular o problema da penalidade com o problema da economia”. (p. 341)

Evidencia-se que o adolescente em conflito com a lei é também uma expressão perfeita do homo oeconomicus. Isso desde a concepção de que, mesmo cometendo ato infracional, o adolescente não deve ser penalizado, mas responsabilizado. A humanização dessa responsabilização consiste em executála mediante um conjunto de medidas, algumas idênticas às penas, determinadas não conforme o ato infracional, sua gravidade, mas sua capacidade de cumpri-la (Art. 112, $\int 1^{\circ}$ ). Como não há dosimetria entre a pena e o crime, outra métrica se sobrepõe: uma medida do próprio adolescente.

As medidas devem representar a "solução que atenda aos interesses do adolescente da forma menos gravosa possível” (Digiácomo \& Digiácomo, 2017, p. 107), o qual deve se beneficiar pedagogicamente. Enquanto as penas possuem caráter retributivo/punitivo, as medidas socioeducativas, com caráter preponderantemente pedagógico, destinam-se unicamente "a educar o adolescente acusado da prática de ato infracional, evitando sua reincidência (Ibid., p. 195). A "intervenção socioeducativa deve procurar combater" as causas da conduta infracional, "sempre da forma menos rigorosa possível” (Ibid., p. 108).

As medidas destinam-se à educação, à formação do adolescente em conflito com a lei, segundo intervenções mínimas, econômicas, plenamente adequadas, segundo um criterioso exame antes e durante a execução da medida, tornando-o apto a retornar à sociedade. A determinação das MSE representa um momento singular. Para determiná-las, é necessário um criterioso exame, considerando-o individualmente, em sua condição peculiar de pessoa em desenvolvimento, mas não segundo um padrão, um homo medius (Idem).

Constituindo o adolescente como o próprio foco e fundamento da medida, já que a atribuição de medida deve visar ao fortalecimento dos "vínculos familiares" e enaltecer "o papel da família no 'processo ressocializador"' (Ibid., p. 107), o exame deve considerar não só o adolescente em diferentes esferas de sua vida, afetiva, familiar, social, mas a "orientação do adolescente" e levar "em conta sua opinião" (Ibid., p. 108).

Este é um ponto crucial para nossa problematização, visto que o foco no sujeito, apresentado no quadro da humanização, da individualização, aponta uma conexão fundamental nos estudos de governamentalidade efetuados por Foucault (1993, 2008a, 2008b, 2018): a interação entre o governo do outro e o governo de si, as práticas de si articulando-se às tecnologias de governo do outro. Segundo Foucault (1993), 


\begin{abstract}
Eu acho que se se quiser analisar a genealogia do sujeito na civilização ocidental, deve-se levar em conta não apenas técnicas de dominação, mas também técnicas de si. Digamos: deve-se levar em conta a interação entre esses dois tipos de técnicas - técnicas de dominação e técnicas de si. Deve-se levar em conta os pontos nos quais as tecnologias de dominação dos indivíduos uns sobre os outros têm recursos a processos por meio dos quais o indivíduo age sobre si mesmo. E, inversamente, deve-se levar em conta os pontos nos quais as técnicas de si são integradas em estruturas de coerção e dominação. O ponto de contato, nos quais o indivíduo é conduzido por outros, está ligado à maneira da qual eles conduzem a si mesmos, e é o que podemos chamar, creio eu, de governo. Governar as pessoas, no sentido amplo da palavra, governar as pessoas não é uma maneira de forçar as pessoas a fazerem aquilo que o governante quer; é sempre um equilíbrio versátil, com complementaridade e conflitos entre as técnicas que asseguram a coerção e os processos por meio dos quais o eu [self] é construído ou modificado por si mesmo. (p. 203 e 204, in Lemke, 2017, pp. 29-30)
\end{abstract}

O ECA estabelece, pela reconfiguração do adolescente como sujeito de direitos, limites para a ação estatal. O ECA produz uma liberdade a ser regulada. Liberdade exigida como um parâmetro da ação governamental: liberdade condicional, melhor, condicionada. Seu exercício não é pleno, mas em desenvolvimento.

No caso do adolescente em conflito com a lei, essa liberdade não se apresenta como uma liberdade a ser completamente respeitada ou reconhecida, com a intervenção sendo evitada ao máximo sob risco de abalar os próprios fundamentos de uma governamentalidade liberal. Aí temos o plano de inserção do neoliberalismo nas políticas destinadas à infância e adolescência no ECA pelo Sistema Nacional de Socioeducação (SINASE).

No neoliberalismo, a governamentalidade também se coordena segundo a liberdade dos indivíduos, conforme a racionalidade desses, mas a liberdade não é mais considerada um dado natural. Ela é artificial. Não é uma liberdade natural dos indivíduos a unidade fundamental, mas um indivíduoempresa (Foucault, 2008b). A reatualização de uma lógica spenceriana, de um darwinismo social, se dá conforme não uma lei biológica, mas segundo uma lógica própria do neoliberalismo.

\footnotetext{
Não se trata mais de uma lógica de promoção geral, mas de um processo de eliminação seletiva. Esse modelo não faz mais da troca um meio de se fortalecer, de melhorar, ele faz dela uma prova constante de confronto e sobrevivência. A concorrência não é considerada, então, como na economia ortodoxa, clássica ou neoclássica, uma condição para o bom funcionamento das trocas no mercado; ela é a lei implacável da vida e o mecanismo do progresso pela eliminação dos mais fracos. (Dardot \& Laval, 2016, p. 53)
}

Todos os fenômenos tornam-se objeto da política econômica e de suas formas de análise. A trama da sociedade é a trama da empresa, do princípio de concorrência, da análise custo-benefício (Foucault, 2008b). Não se trata da lógica de uma promoção geral, do bem-estar social, mas de um processo seletivo de eliminação e promoção. A liberdade do adolescente é uma liberdade artificial, no sentido de que precisa ser construída segundo mecanismos específicos. Sua responsabilização aponta não só uma limitação do Estado, mas a assumência dos riscos, do fracasso e do sucesso resultante da mínima e estritamente necessária intervenção pedagógica das MSE.

Mediante essa tática, torna-se possível não apenas sua responsabilização, mas, sobretudo, o recorte que permite atribuir ao sujeito as consequências por suas escolhas. Ignorando que governo se trata de uma conduta sobre condutas, da manipulação do campo de escolhas possíveis, a governamentalidade neoliberal busca retirar da história o sujeito e circunscrevê-lo apenas em sua história pessoal. Assim, dentre o campo de escolhas manipuladas pela governamentalidade neoliberal para os adolescentes negros e pobres, justificam-se desde a gradação das medidas socioeducativas até seu extermínio pela violência institucionalizada. 
Chegamos ao nosso último ponto. Passaremos então a observar e descrever como a "genealogia do Estado moderno" (Foucault, 2008a, p. 476) corresponde a uma "história do sujeito" (Ibid., p. 243), segundo uma combinação "astuciosa das técnicas de individualização e dos procedimentos de totalização" (Foucault, 1995, p. 236). Em outras palavras, como a constituição do Estado democrático brasileiro, com a promulgação do ECA e com a instituição do Sinase, corresponde à história do adolescente em conflito com a lei.

\section{MEDIDAS SOCIOEDUCATIVAS E A PRODUÇÃO DOS SUJEITOS DE DIREITOS}

Observaremos agora o adolescente em conflito com a lei segundo sua produção pelas MSE. Contudo, as medidas não surgem apenas com o ECA. De fato, elas existem desde o Código Mello Mattos. Neste, elas são distintas segundo a condição de abandonados ou delinquentes, sendo então internados em Escolas de Prevenção ou Reforma, conforme sua caracterização.

No entanto, os parágrafos $2^{\circ}$ e $3^{\circ}$ do artigo 69 do Código, com a expressão "em perigo de o ser" abandonado ou pervertido, acabaram possibilitando a indesejada mistura e a consequente indistinção das instituições executoras das medidas. Apesar de especificar medidas distintas para os casos dos menores aos quais se destinava a prevenção ou a reforma, o Código permitia um arbítrio que acabou por retirar a especificidade das instituições.

No Código de 1979, a Doutrina da Situação Irregular acaba por colocar todos como objetos indistintos da medida já no plano jurídico: qualquer criança ou adolescente, qualquer que seja sua situação, é alvo de Medidas de Proteção. De acordo com seu Capítulo I, as medidas aplicáveis ao menor são: advertência; entrega aos pais ou responsável, ou à pessoa idônea, mediante termo de responsabilidade; colocação em lar substituto; imposição do regime de liberdade assistida; colocação em casa de semiliberdade; e internação em estabelecimento educacional, ocupacional, psicopedagógico, hospitalar, psiquiátrico ou outro adequado. (Art. 14, incisos I - VI).

Vemos então que o conceito de medida, algo que já se inicia como a humanização da resposta do Estado à infração cometida por adolescentes, outrora "menores", não é uma exclusividade do ECA, tampouco a diversidade das medidas, pois algumas são criadas pelo Código de Menores de 1979. O que distingue as medidas do ECA das demais é o seu caráter socioeducativo.

Assumimos que a socioeducação, ou a ação socioeducativa, não se resume ou não está compreendida no conceito de educação social. Ela é um termo definidor e específico da prática educativa destinada a adolescentes em conflito com a lei. Não se pode conceber socioeducação como educação social ou como uma ação social e educativa. Considerando a questão do apoio socioeducativo em meio aberto, vemos:

\footnotetext{
A primeira consideração a ser feita em relação a esse regime é a inadequação do seu nome, que não deveria ser apoio socioeducativo, mas apoio social e educativo em meio aberto. Aqui, estamos diante de um equívoco ocorrido na revisão final do texto do projeto de lei, que passou desapercebida pelos seus formuladores, entre os quais o autor do presente texto.

Ocorreu que, na formulação inicial do artigo sobre os regimes de atendimento, a denominação desse segundo regime de nosso elenco era, precisamente, "apoio social e educativo em meio aberto". No momento da revisão formal - morfologia, sintaxe e estilo -, pareceu mais lógico ao revisor substituir a expressão social e educativo pela forma sintética "socioeducativo".

Acontece, porém, que essa mudança de forma levou a uma importante mudança de conteúdo e distorceu, consideravelmente, a intenção inicial dos formuladores do projeto de lei. A expressão socioeducativo, no
} 
contexto do ECA, nos remete ao universo das medidas aplicadas ao adolescente em conlfito com a lei em razão do cometimento de ato infracional. Essa, entretanto, não era a intenção dos formuladores do projeto de lei ao tipificarem esse regime. (Costa, 2006a, p. 46)

Socioeducação, ou prática socioeducativa, apresenta uma estrita especificidade. Destina-se ao adolescente em conflito com a lei e sua concepção e prática têm uma forma e um objeto específicos. Mas como se fundamenta a socioeducação?

Ninguém melhor para nos responder do que o pedagogo Antônio Carlos Gomes da Costa, cuja experiência como diretor em uma internação feminina em Outro Preto foi descrita no livro Aventura Pedagógica (2001). O sucesso desse livro no período em que justamente se encontravam em crise o Código de Menores, a Funabem e as Febem lhe vale uma série de convites, desde presidente da Febem de Minas até a participação na elaboração do ECA, sendo sua a sugestão de incluir o termo "socioeducativa" no ECA (Raniere, 2014).

Segundo Costa (2006b),

(...) assim como existe educação geral e educação profissional, deve existir socioeducação no Brasil, cujo objetivo é preparar os jovens para o convívio social (...) porque o jovem que cometeu ato infracional, na maioria dos casos, não dá certo na escola, no trabalho e na vida não pela falta de encaminhamentos para a escola ou oportunidades de profissionalização, mas porque lhe faltou acesso a uma educação mais ampla, que lhe possibilitasse aprender a ser e aprender a conviver. (p. 57)

Para Costa, trata-se a socioeducação de uma educação voltada a ensinar a ser e a conviver especificamente destinada ao "jovem que cometeu ato infracional". Mas como se ensinam tais coisas? Segundo Raniere, a proposta de Costa acaba por paralisar o processo de singularização, produzindo uma identidade. Citando Guattari e Rolnik (2000):

\footnotetext{
Identidade e singularidade são duas coisas completamente diferentes. A singularidade é um conceito existencial; já a identidade é um conceito de referenciação, de circunscrição da realidade a quadros de referência, quadros esses que podem ser imaginários. Essa referenciação vai desembocar tanto no que os freudianos chamam de processo de identificação, quanto nos procedimentos policiais, o sentido da identificação do indivíduo - sua carteira de identidade, sua impressão digital, etc. Em outras palavras, a identidade é aquilo que faz passar a singularidade de diferentes maneiras de existir por um só e mesmo quadro de referência identificável. (...) Ora, o que interessa à subjetividade capitalística não é o processo de singularização, mas justamente esse resultado do processo, resultado de sua circunscrição a modos de identificação dessa subjetividade dominante. (pp. 6869, in Raniere, 2014, p. 69)
}

Para Raniere (2014), o pensamento identitário de Costa compreende a experiência existencial como uma série de etapas, degraus, os quais se têm de subir conforme uma obrigação ética. Estabelecendo etapas a serem cumpridas, o adolescente empreende um desenvolvimento gradual de si mesmo, estabelecendo propósitos e metas a serem conquistadas mediante passos coordenados.

Essas etapas são explicitadas no capítulo "O ferramental teórico-prático da socioeducação: métodos e técnicas" do livro Socioeducação: estrutura e funcionamento da comunidade socioeducativa (Costa, 2006b). Interessante notar que os princípios apresentados no texto foram, segundo Costa, extraídos do Paradigma do Desenvolvimento Humano do Programa das Nações Unidas para o Desenvolvimento (PNUD) que apresenta o papel central da educação "para a viabilização da pessoa" (Costa, 2006b, p. 55).

Essa educação é compreendida como o "único processo capaz de transformar o potencial das pessoas em competências, capacidades e habilidades" (Idem). Essa compreensão da educação é alinhada à apresentada por Foucault (2008a) quando coloca a questão do capital humano, conforme 
conceitua a Escola de Chicago, como um exemplo claro da racionalidade neoliberal. É, pois, uma das transformações do homo oeconomicus no neoliberalismo. O próprio

salário nada mais é que a remuneração, que a renda atribuída a certo capital, capital esse que vai ser chamado de capital humano na medida em que, justamente, a competência-máquina de que ele é renda não pode ser dissociada do indivíduo humano que é seu portador. (Foucault, 2008a, p.311 e 312, grifos nossos)

Capital humano esse que é composto por elementos tanto inatos quanto adquiridos (Foucault, 2008a). E é no sentido dos elementos adquiridos que Foucault (2008a) foca sua atenção. Questiona o que quer dizer a formação do capital humano segundo essas espécies de "competênciamáquina" fruto dos investimentos educacionais. Segundo os neoliberais,

(...) o que se deve chamar de investimento educacional, em todo caso os elementos que entram na constituição de um capital humano são muito mais amplos, muito mais numerosos do que o simples aprendizado escolar ou que o simples aprendizado profissional. Esse investimento, o que vai formar uma competência-máquina, será constituído de que? Sabe-se experimentalmente, sabe-se por observação, que ele é constituído, por exemplo, pelo tempo que os pais consagram aos seus filhos fora das simples atividades educacionais propriemante ditas. Sabe-se perfeitamente que o número de horas que uma mãe de família passa ao lado do filho, quando ele ainda está no berço, vai ser importantíssimo para a constituição de uma competência-máquina, ou se vocês quiserem para a constituição de um capital humano, e que a criança será muito mais adaptável se, efetivamente, seus pais ou sua mãe lhe consagraram tantas horas do que se lhe consagraram muito menos horas. Ou seja, o simples tempo de criação, o simples tempo de afeto consagrado pelos pais a seus filhos, deve poder ser analisado em termos de investimento capaz de constituir um capital humano. (Foucault, 2008a, p. 315)

Dessa maneira, toda uma gama de elementos começa ser considerada na constituição de capital humano segundo uma grade econômica. A educação tomada como o desenvolvimento do capital humano, dessa competência-máquina mediante fatores como o tempo, o afeto, o ambiente, a migração, permite à governamentalidade neoliberal gerir a vida dos homens aproveitando suas potencialidades mediante o uso de um sistema de modulação gradual e contínuo de suas capacidades (Foucault, 1987).

É esse sistema de identificação de potencialidades e aperfeiçoamento contínuo de capacidades que observamos articulado à socieducação de Costa. A socioeducação, ao ensinar a ser e a conviver, deve desenvolver atitudes e habilidades. Deve ser uma "atitude básica diante da vida", segundo o "modelo do dano" ou do "desafio", que depende do posicionamento que se assume diante de si e do mundo e de habilidades concebidas como "requisitos básicos para se viver e trabalhar numa sociedade moderna", "habilidades básicas, específicas e de gestão" (Costa, 2006b, p. 56). Critérios fundamentais, mais que o conteúdo, pois se

Os conhecimentos variam conforme cada época e cultura (...) Os valores são tudo o que pesa na hora em que o ser humano tem que tomar uma decisão. (...) as oportunidades de per si não bastam. As pessoas devem ser dotadas de bons critérios para avaliar e tomar decisões fundamentadas. (...) A educação deve propiciar o desenvolvimento dessa capacidade ao educando, possibilitando que ele vivencie, identifique e incorpore valores estruturantes em sua formação. (Costa, 2006b, p. 56, grifos do autor)

Daí a importância de se executar métodos e técnicas próprias à socioeducação que devem contemplar as três dimensões do educando: a dimensão pessoal (educação para valores), a dimensão como cidadão (protagonismo juvenil) e a sua dimensão como futuro profissional (cultura da trabalhidade).

$\mathrm{Na}$ dimensão pessoal, observando a questão do investimento educacional para além do restrito ensino escolar e profissional, a formação dos valores deve pautar-se por técnicas que orientem 
cada um dos sucessivos passos. São 12 passos apresentados por Costa (2006b, p. 59), iniciando na identidade, que consiste em compreender-se e aceitar-se. Seguem então os demais:

2. Autoestima (gostar de si próprio, autoapreciar-se);

3. autoconceito (ter uma ideia boa a respeito de si mesmo);

4. autoconfiança (apoiar-se primeiro em suas próprias forças);

5. visão positiva do futuro (olhar o futuro sem medo);

6. querer-ser (desejar ardentemente ser alguma coisa: sonho);

7. projeto de vida (é querer algo e saber o que é necessário para chegar lá);

8. sentido da vida (é a linha, a estrada, o caminho que liga o ser ao querer-ser);

9. autodeterminação (assumir a direção, o controle de sua própria vida);

10. resiliência (resistir à diversidade e utilizá-la para crescer);

11. autorrealização (cada passo dado na direção do seu projeto);

12. plenitude humana (encontro do ser com o querer-ser).

Seguindo esses passos, os socioeducadores devem propiciar mais que conteúdo ou oportunidades. Devem propiciar algo de outra ordem, da ordem do desejo. Devem fomentar o "desejo genuíno de estudar, aprender, trabalhar, realizar-se (querer-ser) (Costa, 2006b, p. 61), o que exige a pedagogia da presença. Essa é um método "supersimples" que consiste em uma autoeducação do socioeducador em "escutar e observar o conjunto dos acontecimentos reais que acontecem ante os seus olhos" (Ibid., p.71). Mediante essa observação "atenta e metódica dos comportamentos", serão descobertas no socioeducando "aptidões e capacidades que apenas um balanço criterioso e sensível permitirá despertar e desenvolver." (Idem).

Na dimensão cidadã, a educação deve, sem abandonar a "dimensão discursiva", privilegiar a “dimensão pragmática, a dimensão da ação, a dimensão do aprender a fazer, fazendo" (Ibid., p. 84), porque os jovens da atualidade não são os mesmos do passado. Eles são mais "pragmáticos", agrupamse "não pela forma de pensar", mas pela "forma de sentir uma determinada situação, de posicionar-se diante dela e de querer transformá-la no aqui e agora". "Eles têm um grande respeito pela identidade, autonomia e dinamismo de cada pessoa." (Ibid., p. 84).

Os jovens, dentre os quais se situa o adolescente em conflito com a lei, já são compreendidos como o homem pragmático, o self-made man. A própria natureza conforma-se às demandas neoliberais. $\mathrm{O}$ adolescente atual "evolui" para o homem pragmático, não mais o sonhador, agitador e idealista, outrora perigoso na concepção ditatorial.

Ao adolescente em conflito com a lei, destina-se a educação em sua dimensão cidadã que ocorre conjuntamente com a dimensão pessoal, pois são inseparáveis, de acordo com Antônio Carlos. Educação esta que não deve ser crítica, que não deve privilegiar o ensino formal ou mesmo o conteúdo, mas que deve tomar como ponto de partida o próprio adolescente. Deve-se partir de suas habilidades, competências e aptidões para adequá-lo às novas exigências do mundo neoliberal. Habilidades, competências e aptidões cujo "desenvolvimento", por uma educação tida como emancipadora, permite o exercício do protagonismo juvenil e assim vença no processo societário compreendido como uma luta entre indivíduos.

Ele deve participar ativamente no próprio processo. Trata-se de um compromisso pessoal, ético e cidadão seguir os passos que o conduzem à plenitude. E se há uma escada para a dimensão humana, também haverá uma escada para a participação do adolescente. Ele é o foco e o centro do Educação em Revista|Belo Horizonte|v.36|e234615|2020 
processo e as medidas socioeducativas, não o tratando como um objeto, mas como um sujeito, devem conduzi-lo da manipulação das medidas dos Códigos à autonomia do Estatuto. Com nove etapas, a escada da participação inicia-se na participação manipulada à participação plenamente autônoma (Ibid., p. 89). O estágio final do sucesso se dá, quando, por si só, age como o empreendedor que se espera que seja.

Por último, a dimensão produtiva, na qual se desenvolverá a "trabalhidade". Essa é a "capacidade de a pessoa ingressar, permanecer e ascender no mundo do trabalho". Ela é "um novo modo de ver, entender, sentir, agir e interagir com o novo mundo do trabalho, transformado pela globalização dos mercados, pela inovação tecnológica e pelas novas formas de organização do processo produtivo (Ibid., p. 90).

Para ingressar e desenvolver a trabalhidade, a educação deve "transformar potencial em competências": a "competência pessoal (aprender a ser)"; a "competência relacional (aprender a conviver)"; a "competência produtiva (aprender a fazer)"; a "competência cognitiva (aprender a conhecer) (Ibid., pp. 91-94).

São essas as dimensões a serem trabalhadas segundo o ferramental teórico e prático que disponibiliza métodos e técnicas da socioeducação. Mas por que tal perspectiva de Costa é importante para as medidas socioeducativas?

São importantes no sentido de que suas concepções referentes à socioeducação impactaram o Sinase. O livro citado é apenas um de um conjunto de livros que são apresentados como "guias elaborados pelo consultor Antônio Carlos Gomes da Costa objetivando contribuir para a formação de operadores e gestores do sistema socioeducativo no Brasil”' (Costa, 2006c, p. 5) pela Secretaria Especial de Direitos Humanos. Os livros oferecem, antes da elaboração do Sinase, orientações para a execução da socioeducação.

Afinal, com a promulgação do Estatuto, toda a trama institucional não se modifica da noite para o dia. O período de transição entre o Código de Menores e o ECA mostrou-se difícil. O corpo de técnicos requer orientações e o Sinase se apresenta, em 2012, como a lei que institui o Sistema Nacional de Atendimento Socioeducativo (Lei n. ${ }^{\circ}$ 12.594, 2012) e regulamenta a execução das medidas. Ao fazêlo, porém, não se pode ignorar todo um conjunto de propostas já realizadas. Assim, embora o próprio Sinase forneça diretrizes, ele não se apresenta como um referencial teórico (Bisinoto et al., 2015). Não apresenta uma teoria do trabalho socioeducativo, mas um conjunto de ideias, métodos e técnicas que se coordena com normativas internacionais e com uma racionalidade neoliberal do indivíduo-empresa como detentor de "capital humano".

Toda uma concepção do homo oeconomicus do neoliberalismo impregna o Sinase e a execução das medidas socioeducativas mediante o conceito de socioeducação. Termo que traz toda a ótica do empreendedorismo, do homem-empresa, como a lógica que perpassa o atendimento socioeducativo.

O envolvimento de Antônio Carlos com a perspectiva do empreendedorismo influencia o Sinase como estratégia de controle. Também a identidade é agenciada no Sinase pelo Plano Individual de Atendimento (PIA) (Lei n. ${ }^{\circ}$ 12.594, 2012, Art. 52), que consiste na elaboração de planos e metas pelo adolescente juntamente com sua família e equipe.

Apontando a coordenação de tecnologia de si e tecnologia de governo do outro, o PIA é uma tecnologia que perpassa praticamente todas as medidas socioeducativas - excetuando a advertência 
e a obrigação de reparar o dano - e representa a passagem da tecnologia mecânica das medidas dos Códigos para os objetos da lei no projeto de sujeitos de empreendimento do ECA.

O PIA apresenta-se como uma articulação entre as tecnologias de si e as tecnologias de dominação. Articula os modos pelos quais o próprio adolescente busca se conduzir para estabelecer uma tecnologia de dominação ao instituir um campo de possibilidades que deve constar no projeto socioeducativo, como a educação ou o trabalho, mesmo que essas questões não se configurem para o adolescente como objetivos ou propósitos. Ele manipula um campo de possibilidades já estabelecidas que se conformam como campos necessários à atuação socioeducativa e busca ativar no adolescente os modos pelos quais ele busca conduzir a si mesmo para atingir essas metas.

Ainda que o adolescente recuse essas metas, ele não está livre delas, as quais se tornam referenciais negativos que demonstram a necessidade de permanência nas medidas ou a inadequação da medida, tendo em vista o comprometimento do adolescente com outros propósitos prejudiciais a si e à sociedade.

O PIA constitui-se como um "instrumento de previsão, registro e gestão das atividades a serem desenvolvidas com o adolescente", contemplando a "participação dos pais ou responsáveis" que têm o "dever de contribuir com o processo ressocializador" (Lei n. ${ }^{\circ} 12.594$, 2012, art. 52, parágrafo único). Nele deve constar, no mínimo, segundo os incisos I ao VI do artigo 54:

I - os resultados da avaliação interdisciplinar;

II - os objetivos declarados pelo adolescente;

III - a previsão de suas atividades de integração social e/ou capacitação profissional;

IV - atividades de integração e apoio à família;

$\mathrm{V}$ - formas de participação da família para efetivo cumprimento do plano individual; e

VI - as medidas específicas de atenção à sua saúde. (Lei n. $\left.{ }^{\circ} 12.594,2012\right)$

As medidas socioeducativas coordenam identidade, responsabilidade e protagonismo mediante instrumentos que unem tecnologias de dominação e tecnologias de si.

Para se responsabilizar, torna-se necessário identificar. Uma identificação que seja capaz de conduzir à responsabilização e à ressocialização de acordo com a incitação ao protagonismo juvenil. Protagonismo cerceado em um campo de possíveis ordenado por uma governamentalidade neoliberal, já que não se trata de singularidade, de autocondução, de autoformação.

Paralisando a singularidade na identidade, estabelece-se uma série de quadros referenciais que deve levar o adolescente à plenitude empreendedora segundo tecnologias que reconheçam suas habilidades e aptidões e o conduzam ao estabelecimento de metas e aos meios de atingi-las. Ela ativa o adolescente, torna-o responsável por si mesmo, por seu fracasso e seu sucesso. Estimula-se o adolescente como um empreendedor motivado pelo desafio capaz de perseverar até a vitória. Vitória essa que não corresponde a uma singularidade, a um projeto de si, mas a um projeto no qual participa, segundo moldes preestabelecidos, conforme a racionalidade que a institui.

Forma-se, então, a imagem do adolescente em conflito com a lei. O sujeito que emerge com a prática socioeducativa, mais uma objetivação do caleidoscópio adolescente: sujeito jurídico, livre, responsabilizável, protagonista de sua história, que, investido adequadamente, desenvolverá habilidades e competências que lhe permitirão empreender para além do quadro histórico e social estigmatizante de todo um grupo social. 


\section{CONSIDERAÇÕES FINAIS}

Todas as práticas heterogêneas que objetivaram ao adolescente em conflito com a lei, ao longo dos séculos XX e XXI, encontram-se ainda hoje fragmentando-o em uma dinâmica de forças permanentemente tensionada. A governamentalidade neoliberal, ao produzi-lo conforme sua grade de inteligibilidade, desenvolveu tecnologias refinadas ao operarem conforme o equilíbrio delicado das tecnologias de dominação e as tecnologias de si. Elas permitem a formação de uma subjetividade para o adolescente em conflito com a lei: o de responsável por sua própria desgraça ou salvação em uma sociedade formada por indivíduos-empresas, selecionados conforme suas habilidades e competências, para o sucesso ou a falência.

Desde o início do século XX, governamentalidades distintas se destinaram a refletir acerca da prática de governo da infância e da adolescência. Nesse processo, saberes distintos articularam-se ao Estado, conformando o adolescente como um problema de Estado e um problema científico, cuja solução só poderia ser dada mediante uma ação concertada entre eles.

Observamos então a emergência do "menor" e de técnicas biopolíticas que, mesmo originárias de uma governamentalidade liberal, se viram no contexto brasileiro postas em funcionamento segundo diferentes governamentalidades que encontravam no próprio Estado a legitimidade e o objetivo último da prática. Apenas com a ruptura provocada pela própria redemocratização, as técnicas biopolíticas se desenvolvem no quadro de uma governamentalidade liberal que limita as pretensões do Estado no que concerne à criança e ao adolescente.

Nesse quadro, conformam-se a criança e o adolescente não só em sua acepção biológica e universal, mas como sujeitos de direitos. É nessa junção que se reconfigura o dispositivo da adolescência e emerge um novo adolescente objetivado segundo novas práticas. À medida que se desenvolvem e se especificam os mecanismos de controle, as tecnologias cada vez mais refinadas buscam coordenar as tecnologias de dominação com as tecnologias de si, que o adolescente em conflito com a lei começa por se tornar a personagem objetivada segundo uma governamentalidade neoliberal que determina atualmente as medidas de sua existência.

\section{REFERÊNCIAS}

Bisinoto, C., Oliva, O. B., Arraes, J., Galli, C. Y., Amorim, G. G. \& Stemler, L. A. S. (2015). Socioeducação: origem, significado e implicações para o atendimento socioeducativo. Psicologia em Estudo, 20(4), 575-585. Doi: 10.4025/psicolestud.v20i4.28456

Cassoli, T. (2016). Humanização, psicologia e riso: produção de liberdade e processos de subjetivação. Revista Polis e Psique, 6(2), 109-133. Doi: https://doi.org/10.22456/2238-152X.64004

César, M. R. A. (2008). A invenção da adolescência no discurso psicopedagógico. São Paulo: Editora Unesp.

Constituição da República Federativa do Brasil de 1988. Recuperado em 10 maio, 2019, de http://www.planalto.gov.br/ccivil 03/constituicao/constituicao.htm

Convenção sobre os Direitos da Criança. (1989). Adotada pela Assembleia Geral das Nações Unidas em 20 de novembro de 1989; promulgado pelo Decreto n. ${ }^{\circ}$ 99.710, de 21 d novembro de 1990. Recuperado 
em 30 maio, 2019, de

http://www.crianca.mppr.mp.br/modules/conteudo/conteudo.php?conteudo $=1070$

Costa, A. C. (2001). Uma aventura pedagógica: caminhos e descaminhos de uma ação educativa. Belo Horizonte: Modus Faciendi.

Costa, A. C. (2006a). Os regimes de atendimento no Estatuto da Criança e do Adolescente: perspectivas e desafios. Brasília: Secretaria Especial de Direitos Humanos.

Costa, A. C. (2006b). Socioeducação: estrutura e funcionamento da comunidade educativa. Brasília: Secretaria Especial de Direitos Humanos.

Costa, A. C. (2006c). Parâmetros para a formação do socioeducador: uma proposta inicial para reflexão e debate. Brasília: Secretaria Especial de Direitos Humanos.

Dardot, P. \& Laval, C. (2016). A nova razão do mundo: ensaio sobre a sociedade neoliberal. São Paulo: Boitempo.

Declaração de Genebra. (1924). Recuperado em 30 maio, 2019, de http://cpd.org.rs/wpcontent/uploads/2017/11/01 - Declaration of Geneva 1924.pdf

Declaração Universal dos Direitos da Criança. (1959). Adotada pela Assembleia das Nações Unidas de 20 de novembro de 1959 e ratificada pelo Brasil. Recuperado em 30 maio, 2019, de http://www.crianca.mppr.mp.br/pagina-1069.html

Declaração Universal dos Direitos Humanos. (1948). Adotada e proclamada pela Assembleia Geral das Nações Unidas (resolução 217 A III) em de dezembro de 1948. Recuperado em 30 maio, 2019, de https://www.unicef.org/brazil/declaracao-universal-dos-direitos-humanos

Decreto n. ${ }^{\circ} 17.943-A$, de 12 de outubro de 1927. (1927). Consolida as leis de assistência e proteção a menores. Recuperado em 30 maio, 2019, de http://www.planalto.gov.br/ccivil 03/decreto/19101929/D17943Aimpressao.htm

Digiácomo, M. J. \& Digiácomo, I. A. (2017). Estatuto da Criança e do Adolescente anotado e interpretado ( $7^{\mathrm{a}}$ ed.). Curitiba: Fundação Escola do Ministério Público do Paraná. Recuperado em 16 agosto, 2019, de http://femparpr.org.br/site/wp-content/uploads/2017/07/Livro-ECA.pdf

Diretrizes de Riad. Diretrizes das Naçoes Unidas para Prevenção da Delinquência Juvenil. (1988). O oitavo Congresso das Nações Unidas sobre prevenção do delito e do tratamento do delinquente.

Recuperado em 30 maio, 2019, de http://www.crianca.mppr.mp.br/modules/conteudo/conteudo.php?.conteudo $=1075$

Faleiros, V. P. (2011). Infância e processo político no Brasil. In Rizzini \& Pilotti (Orgs.), A arte de governar crianças: a história das politicas sociais, da legislação e da assistência à infância no Brasil (3a ed.). (pp. 33-96). São Paulo: Cortez.

Feitosa, J. B. \& Boarini, M. L. (2014). The defense os Socio-educational internment: feature of the hygienist principles. Paidéia, 24(57), 125-133. Doi: 10.1590/1982-43272457201415

Fórum Brasileiro de Segurança Pública. (2019). Anuário Brasileiro de Segurança Pública. Recuperado em 16 agosto, 2019, de http://www.forumseguranca.org.br/wp-content/uploads/2019/10/Anuario-2019FINAL 21.10.19.pdf 
Fórum Brasileiro de Segurança Pública. (2019). Atlas da Violência 2019. Recuperado em 16 agosto, 2019, de http://www.forumseguranca.org.br/wp-content/uploads/2019/06/Atlas-da-Violencia2019 05jun vers $\%$ C3\%A3o-coletiva.pdf

Foucault, M. (1979). Microfísica do Poder (11ª ed.). Rio de Janeiro: Edições Graal.

Foucault, M. (1987). Vigiar e punir: nascimento da prisão (7a ed.). Petrópolis, RJ: Vozes.

Foucalt, M. (1993). About the beginning of the hermeneutics of the self: two lectures at Dartmouth. Political Theory, 21(2), 198-227. Recuperado em 15 de maio, 2019, de http://www.jstor.org/stable/191814

Foucault, M. (1995). O sujeito e o poder. In Dreyfus, H \& Rabinow, P. (1995). MichelFoucault, uma trajetória filosófica: para além do estruturalismo e da hermenêutica. Rio de Janeiro: Forense Universitária.

Foucault, M. (2008a). Nascimento da biopolítica. Curso dado no Collège de France (1978-1979). São Paulo: Martins Fontes.

Foucault, M. (2008b). Segurança, território, população. Curso dado no Collège de France (1977-1978). São Paulo: Martins Fontes.

Foucault, M. (2018). História da sexualidade 1: a vontade de saber (7 ${ }^{\mathrm{a}}$ ed.). Rio de Janeiro/São Paulo: Paz e Terra.

Giangarelli, P. M. \& Rocha, A. P. (2011). Adolescente privado de liberdade: um estudo dos argumentos do Judiciário para aplicação de medida socioeducativa de internação. Serviço Social em Revista, 14(1), 173 197. Doi:10.5433/1679-4842.2011v14n1p173

Guattari, F. \& Rolnik, S. (2000). Micropoliticas: cartografias do desejo. Petrópolis: Editora Vozes.

Lei n. ${ }^{\circ}$ 12.594, de 18 de janeiro de 2012. (2012). Institui o Sistema Nacional de Atendimento Socioeducativo (SINASE), regulamenta a execução das medidas socieducativas destinadas a adolescente que pratique ato infracional; e altera as Leis no ${ }^{\circ}$ 8.069, de 13 de julho de 1990 (Estatuto da Criança e do Adolescente); 7.560, de 19 de dezembro de 1986, 7.998, de 11 de janeiro de 1990, 5.537, de 21 de novembro de 1968, 8.315, de 23 de dezembro de 1991, 8.706, de 14 de setembro de 1993, os Decretos-Leis n ${ }^{\circ}$ s 4.048, de 22 de janeiro de 1942, 8.621 de 10 de janeiro de 1946, e a Consolidação das Leis do Trabalho (CLT), aprovada pelo Decreto_lei n. ${ }^{\circ}$ 5.452, de $1^{\circ}$ de maio de 1943.

Lei n. 6.697, de 10 de outubro de 1979. (1979). Institui o Código de Menores. Recuperado em 30 maio, 2019, de http://www.planalto.gov.br/ccivil 03/leis/1970-1979/L6697impressao.htm

Lei n. ${ }^{\circ}$ 8.069, de 13 de julho de 1990. (1990). Dispõe sobre o Estatuto da Criança e do Adolescente e dá outras providências. Brasília: Presidência da República.

Lemke, T. (2017). Foucault, governamentalidade e crítica. São Paulo: Editora Filosófica Politeia.

Méndez, E. G. (2001). Infância, lei e democracia: Uma questão de Justiça. In Méndez, E. G. \& Bellof, M. (Orgs.), Infância, lei e democracia na América Latina: análise crítica do panorama legislativo no marco da Internacional dos Direitos da Criança (1990-1998). (pp. 21-45). Blumentau: EDIFURB.

Méndez, E. G. (2006). Evolução histórica do Direito da Infância e da Juventude. In ILANUD, ABMP, SEDH \& UNFPA (Orgs.), Justiça Adolescente e Ato Infracional: socioeducação e responsabilização. 
Ministério da Justiça e Segurança Pública-Departamento Penitenciário Nacional. (2017). Levantamento Nacional de Informações Penitenciárias Atualização - Junho de 2017. Recuperado em 30 maio, 2019, de http://depen.gov.br/DEPEN/depen/sisdepen/infopen/relatorios-sinteticos/infopen-jun-2017-rev12072019-0721.pdf

Ministério dos Direitos Humanos. (2018). Levantamento Anual SINASE 2016. Recuperado em 16 agosto, 2019, de https://www.mdh.gov.br/navegue-por-temas/crianca-eadolescente/Levantamento 2016Final.pdf

Passeti, E. (2016). Crianças carentes e políticas públicas. In Del Priore, M. (Org.), História das Crianças no Brasil (7 ed.). (pp. 347-376). São Paulo: Contexto.

Raniere, E. (2014). A invenção das medidas socioeducativas. Tese de doutorado, Universidade Federal do Rio Grande do Sul, Porto Alegre. Recuperado em 30 julho, 2019, de https://lume.ufrgs.br/handle/10183/87585

Regras de Beijing. Regras Mínimas das Nações Unidas para a Administração da Justiça da Infância e da Juventude (1985). Adotadas pela Assembleia Geral das Nações Unidas na sua resolução 44/33, de 29 de novembro de 1985. Recuperado em 30 amio, 2019, de http://www.crianca.mppr.mp.br/modules/conteudo/conteudo.php?conteudo $=1074$

Rivera, D. (1989). 2ª Mesa: "Posicionamento da Sociedade Civil frente ao Estatuto e ao Código de Menores". In A criança e seus direitos: Estatuto da Criança de Adolescente e Código de Menores em Debate. (ps. 39-59). Rio de Janeiro, RJ/Brasil: Funabem/PUC-Rio.

Rizzini, Irma. (2011). Meninos desvalidos e menores transviados: a trajetória da assistência pública até a Era Vargas. In Rizzini \& Pilotti (Orgs.), A arte de governar crianças: a história das políticas sociais, da legislação e da assistência à infância no Brasil ( $3^{\mathrm{a}}$ ed.). (pp. 225-286). São Paulo: Cortez.

Rizzini, Irene \& Celestino, S. (2016). A cultura da institucionalização e a intensificação das práticas de confinamento de crianças e adolescentes sob a égide da Funabem. In Freitas (Org.). História Social da Infância no Brasil (9a ed. rev. e ampl.). (pp. 229-250). São Paulo: Cortez.

Saraiva, J. B. C. (2016). Adolescente e responsabilidade penal: da indiferença à proteção integral (5a ed.). Porto Alegre: Livraria do Advogado Editora.

Sennellart, M. (2006). As artes de governar. São Paulo: Editora 34.

Submetido: $01 / 03 / 2020$

Aprovado: $16 / 05 / 2020$ 